KYIV-MOHYLA

HUMANITIES JOURNAL

KYIV-MOHYLA SCHOLARLY PEER-REVIEWED JOURNALS

\title{
Author and Authorship in Dymytriy Tuptalo's Lives of the Saints
}

\section{Author: Dariya Syroyid}

Source: Kyiv-Mohyla Humanities Journal 2 (2015): 99-108

Published by: National University of Kyiv-Mohyla Academy

http://kmhj.ukma.edu.ua/ 


\title{
Author and Authorship in Dymytriy Tuptalo's Lives of the Saints
}

\author{
Dariya Syroyid \\ Ukrainian Catholic University, \\ Department of Classical, Byzantine, and Medieval Studies
}

\begin{abstract}
The Lives of the Saints compendium by Dymytriy Tuptalo belongs to a special type of rewritten literature representing a collection of already existing and retold texts. The paper discusses how numerous authors, often distanced in time, can coexist within one text. It focuses on the combination of various (medieval and early modern) approaches in the gathering of a hagiographical collection, as well on Tuptalo's individual traits as a hagiographer-compiler, his original source processing, and his collaboration with predecessors. The paper attempts to reveal the characteristic features of the compendium that provide a better understanding of the concept of the author and authorship in the process of metaphraseis.
\end{abstract}

Key Words: author, authorship, Lives of the Saints, rewriting, paraphrase, metaphraseis, menologion.

Lives of the Saints [Chetii-Minei; Menologion] is a special type of hagiographical collection arranged by the dates of an ecclesiastical year. The main goal of rewriting texts in such a collection was to adapt much older texts to the needs of the time when they were being rewritten. This was often done on Church demand. In most cases re-working of the texts was only literary since it had to deal just with the form of the text. The hagiographer-compiler is very rarely the author of the original texts about new saints, and even if he is, he authors only very few of them. Nevertheless, he becomes the creator of the particular collection of the texts, and today all known compendiums are known by the names of their compilers. Tuptalo's Lives of the Saints is closely associated with his name and is considered the "work of his life." Other hagiographical collections can similarly be attributed to other text compilers from Symeon Metaphrastes to Piotr Skarga. In some cases a collection is associated not with a writer, but with a Church official, for example The Great Menologion is attributed to Makarius of Moscow. In every case such rewriting raises questions about author and authorship. Each compiler solves it in his own manner depending on the personality of both writer and re-writer.

In various historical periods authorship was influenced by the tradition of rewriting and the perception of the authority of the author. The tradition of rewriting and retelling the lives of saints existed long before the Tuptalo's time. Claudia Rapp argues, that "a first flourishing of the composition of metaphraseis of saints' Lives occurred in the seventh century" and was connected with the names of Sophronius, Patriarch of Jerusalem, George, Patriarch 
of Alexandria, Leontius of Neapolis and other hagiographers, known also as biographers of contemporary holy men. ${ }^{1}$ The most famous re-written hagiographical collection dates back to the 9 th century and consists of 148 texts. Its author, Symeon Metaphrastes, established a new tradition of rewriting hagiography in new style and form. Although Claudia Rapp disproves "the traditional appreciation of Symeon Metaphrastes as the great innovator," ${ }^{2}$ in context of our conversation about Tuptalo's compendium we have to consider the great authority of Metaphrastes (and even a fashion on him) in Tuptalo's time.

Christian Høgel claims that "Symeon Metaphrastes did not compose texts on new saints, but some texts used several sources in a sufficiently free way to deserve the label of new compositions." ${ }^{3}$ Discussing the work process of Symeon Metaphrastes, Høgel tells us about four procedures: "1. The text was incorporated into the menologion in an already existing version; in some cases with a new prologue and ending. The name of the original author was, at least in some cases, retained in the title [14 or 18 texts]. 2. The text was rephrased (metaphrased) orally, taken down in short-hand and thereafter copied into normal script. Additional information from other sources was in some cases included, either cited or metaphrased [around 120 texts]. 3. A new narrative was composed on the basis of several sources [...] [8 texts]. 4. In a few cases, Symeon may have contaminated the stories of two different (groups of) saints into one text) [2 texts]." ${ }^{4}$

Only the second procedure is very unique to Metaphrastes and became known to researchers thanks to his biographer Michael Psellos. ${ }^{5}$ The rest of the approaches of metaphrase is could be used by other hagiographers too, including Dymytriy Tuptalo. Over the centuries this tradition continued without significant changes. Hagiographical texts were consolidated (The Great Menologion by Makarius) or re-written (Żywoty Swiętych by Piotr Skarga), and often the personality of the previous author was not particularly important for the re-writers. Moreover, the concept of author was often identified as the concept of source, ${ }^{6}$ and the main motivation to write the name of the previous author (or source) was the desire to persuade the reader

$1 \quad$ Claudia Rapp, "Byzantine Hagiographers as Antiqurians, 7th to 1oth Century," in Bosphorus, ed.

C. Rapp, S. Efthymiadis and D. Tsougarakis (Amsterdam,1995), 35.

2 Rapp, "Byzantine Hagiographers," 43.

3 Christian Høgel, Symeon Metaphrastes: Rewriting and Canonization (Copenhagen: Museum Tusculanum Press, 2002), 11.

4 Høgel, Symeon Metaphrastes, 92.

5 See more in Høgel's book.

6 Concerning the sources of Tuptalo's Chetii-Minei, there are some discrepancies between the notations and references in the text, evidenced by Tulptalo's Diary and the results of research. They may have been induced by censorship of the Moscow Patriarch (for example, the work of O. Derzhavin about Chetii-Minei: Alexandr Derzhavin, "Chetii-Minei sviatitelia Dimitria, mitropolita Rostovskogo, kak tserkovnoistoricheskii i literaturnyi pamiatnik," ["The Chetii-Minei of Dmytro, Metropolitan of Rostov, as Clerical, Historical, and the Literary Evidence,"] Bogoslovkie trudy 15 (1976): 61-145; Teoktyst Pachovskyi, "Knyha Zhytii sviatykh' Dmytra Tuptalenka-Rostovskoho," ["Dmytro Tuptalenko-Rostovskyi's Lives of the Saints,"] in Dmytro Tuptalo u sviti ukrainskoho baroko, ed. Bohdana Krysa (Lviv: Artos - Apriori, 2007), 221-26. 
in the credibility of the text. This fixation on the reader defined a circle of fashionable and "credible" authors, and was the reason why Piotr Skarga in his compendium made reference to Metaphrastes, but not to Surius (the real source). ${ }^{7}$ This also introduces one more common feature: the re-written texts received more relaxed rules of the genre. The unchangeable for centuries saints' lives were retold more freely. Each new narrator put more emphasis on different moments in the plot, shaping it in his own way for his own purpose. In his search for information the compiler often used non-hagiographical sources. As a result many texts such as the patericon, church history, memoirs, Bible Stories, synaxarion, etc. were converted into hagiography, with the author's interpretation. Without a doubt, it was the manifestation of baroque style and baroque consciousness.

However this early modern time added one more aspect to the attitude towards literary heritage. Since the early $17^{\text {th }}$ century, due to the activity of the Bollandists, ${ }^{8}$ hagiographical collections began to be viewed as a scientific process, collections for conservation. And the position of Tuptalo balanced between the two concepts of a hagiographical collection: rewriting in a new form for the comfortable reading by contemporary readers, and for the needs of the Church; and on the other hand - rewriting as an initial kind of scientific processing for the purpose of collecting all available information about the saints found in all sources by all known authors. In the latter case such things as reference to a source and previous author were very important for Tuptalo. It is notable that he gave no preference to some saints over others (as did Metaphrastes or Skarga, acting on the principle "one day - one saint"). On the contrary, seeking completeness, he carefully collected them mentioning all of them on "their day."

But for Tuptalo, completeness was not the only goal. The criterion of certainty and legitimacy was the main one. The best illustration of this is his version of the Life of Saint Tekla (September 24). He could possibly use two sources: the apocryphal Acts of Paul and Thekla (not mentioned by Tuptalo, but well-known to readers of his period in its Church-Slavonic translation ${ }^{9}$ ); and its fifth-century paraphrase: The Life and Miracles of Thekla, mentioned by Tuptalo several times as the work of Basil of Seleukeia, ${ }^{10}$ and possibly known to him from the Acta Sanctorum. In comparison with other hagiographic texts of St. Dymytriy's collection, this one is compendious and less informative. The reason is that Tuptalo chose for his narrative only

7 Andrea Ceccherelli, “Od Suriusa do Skargi / Studium porównawcze o “Żywotach świętych', in Nauka o literaturze polskej za granica, pod redakcją naukową Aliny Nowickiej-Jeżowej, tom VIII), trans. Monika Niewójt (Warszawa: Świat Literacki, 2003), 46.

8 We have to mention also other hagiographical collections, for example those assembled by Laurentius Surius and Aluiso Lippomann.

9 For example, the text in "Great Menologion" identified as "The Life of Thekla" and actually identical to the one in the manuscript from Zamostia published by Ivan Franko in his "Apokryfy i lehendy z ukrainskykh rukopysiv," [“Apocrypha and Legends in Ukrainian Manuscripts,"] in Apokryfy novozavitni, apokryfichni diiannia apostoliv, ed. Ivan Franko (Lviv, 2006), 33-45.

10 The authorship of fifth-century bishop Basil of Seleukia was refuted by Gilbert Dagron. See more about this and comparison of both texts in: Scott Fitzgerald Johnson, The Life and Miracles of Thekla: A Literary Study (Cambridge, MA and London: Harvard University Press Center for Hellenic Studies, 2006). 
the episodes confirmed by the Church Fathers who used them in their homilies. The authority of John Chrisostom, Gregory of Nyssa, Epiphanius, Cyprian, John Damascene, Ambrose, and Jerome provided legitimacy to the non-biblical apostolic figure of Saint Thekla.

The decision of what to do with the previous author depends on many circumstances, the main of which is the authority of the author. It is necessary to mention that a great deal of hagiography was authorless, especially the martyrdoms. ${ }^{11}$ Some of them were rewritten by Symeon Metaphrastes and in this case he became the author. But interference of such an author with the text is minimal, because he is not a witness and his narrative is devoid of the values of first evidence. We have an opposite situation in the works describing the lives of monks written by their disciples. Such an author was not only a narrator, but also a witness of the holy life and sometimes a participant in the story. The presence of this author in the text is the chief evidence of the sanctity of the saint hero. Furthermore, his role in the text is very interesting and complicated, as suggested by the research of Derek Krueger. He describes the process of writing the saint's life as "a highly ritualized technology," "doubly generative, producing both the saints and their authors." 12

The relationship between the saint and his new hagiographer is not the same. That is not to say that it was not a spiritual practice and a special experience of communication with the saint. After all, the life of a saint doesn't end with his/her death, it continues and is manifested in miracles and the support of people who pray to the saint. Each of the rewritten texts becomes the story of new experience, the actualization of heroism of the saint for the re-writer (and accordingly for the reader), new evidence and testimony.

Tuptalo's diary opens for us a mystical story of hagiographical rewriting. Definitely, some texts in the collection were particularly intimate for him. One of them was The Life of the Saint Barbara. Possibly this is not surprising, because in Tuptalo's time her saint relics were found in St. Michael's Golden-Domed Monastery in Kyiv, and little Dymytriy could have inherited the feeling of deep veneration for this saint from his mother, suggests A. Derzhavin. ${ }^{13}$ Interestingly, Tuptalo describes an experience of "an oneiric communication" with Saint Barbara in his diary (mentioned under the year of 1685).14 This likely resulted in his great inspiration. ${ }^{15} \mathrm{He}$ did not directly mention his work on The Life of the Saint Barbara, but the dream about the need for

11 It was an object of worry. As Christian Høgel writes about Theodore Stoudites: "Theodore thus comforts his pupil with a pragmatic response to what seems a justified worry: if anonymous, how can texts carry authority? The same worry seems to have struck the compiler of the later synaxarion, who says he collected his material "placing the reliability of the accounts on the shoulders of those who first wrote about them [the saints] [Delehaye, Synaxarium, xiii]." Høgel, Symeon Metaphrastes, 47.

12 Derek Krueger, Writing and Holiness. The Practice of Authorship in the Early Christian East (Philadelphia: University of Pennsylvania Press, 2004), 2.

13 A. Derzhavin, Chetii-Minei sviatitelia Dimitria, mitropolita Rostovskogo, 88-89.

14 Dymytriy Tuptalo, "Diariush," ["Diary,"] in Pamiatna knyha Dmytra Tuptala, ed. Valentyna Sobol (Warsaw: Uniw. Warszawski, 2004), 36-37.

15 The other "oneiric communication" was the communication with the holy martyr Orestes in his dream, which Tuptalo mentioned under 1689 but which actually occured in 1685 as well. In the dream the martyr made some corrections to Tuptalo's narrative, accusing him of underestimating 
a new shrine for the Saint's relicts is mentioned in his diary and could have been inspired by the process of rethinking a new form of a story about her Life, suggests Petro Bilous. ${ }^{16}$

At the beginning of the text about St. Barbara, in a margin, Dymytriy noted the three sources: the Menologion by Metaphrastes, a text by John Damascene (maybe his homily) and the collection by Makarius (of Moscow). After a thorough study of this fact, Marina Fedotova ${ }^{17}$ proposed that all the three sources (not directly, but through the mediation of some other texts) were known to Tuptalo. Yet he created completely a new, very scrupulously written version of St. Barbara's life. The size of Tuptalo's text is much larger than the sources', it has no informational gaps, it is complete in all aspects ranging from content to emotions. A similar situation is observed in another Tuptalo tale about Saint Barbara's relics, based on a text of Theodosius Sophonovich (Tuptalo noted this source in a margin). Dymytriy complements and rewrites this story as well. ${ }^{18}$

In the Tuptalo text dedicated to Saint Barbara we can notice his cooperation with his predecessors: Symeon Metaphrastes and John Damascene. None of them witnessed Saint Barbara's life, but all of them, including Tuptalo himself, were witnesses of St. Barbara's miracles. ${ }^{19}$ This is very important for Tuptalo, and he stresses this fact. The first witness was John Damascene, after him there was Symeon Metaphrast, who (as Tuptalo writes) testified about the healing bath, where he saw a preserved trace of Barbara's foot.

It is hard to say something very specific about Tuptalo's method. Working on each text, the hagiographer collaborated with the previous author (or authors) in different ways. Undoubtedly, the personality of the predecessor was always very important for him. The first step of collecting all available copies of the texts dedicated to a saint provided unequal opportunities for the next stage of processing. It depended not only on the number of texts or copies, but also on the history of the cult of this saint in Rus, as well as on the authority of the author and, on the presence or absence of the author in the text. Such an author (the witness, the disciple and the participant of the story) was Cyril of Scythopolis. Derek Krueger writes about two texts by Cyril — The Life of Euthymius and The Life of Sava - in the context of Cyril's special concept of authorship. ${ }^{20}$

his suffering. This hints that Tuptalo did not stop thinking about his saint heroes even after the completion of works on their lives. See: Tuptalo, "Diariush," 41-42.

16 Petro Bilous, “Pytannia psykholohii tvorchosty v 'Diariushi' Dmytra Tuptala," ["The Problem of the Psychology of Art in Dmytro Tuptalo's Diary,"] in Dmytro Tuptalo u sviti ukrainskoho baroko, ed. Bohdana Krysa (Lviv: Artos - Apriori, 2007), 67.

17 Marina Fedotova, “Zhytie sviatoi Varvary v Drevnei Rusi," [“The Life of St. Barbara in Kyivan Rus,”] in TODRL, vol. 53 (Saint Petersburg, 2003), 76-89.

18 Thus, as M. Fedotova claims, his text was twice longer as the one written by Sophonovich. See: Fedotova, "Zhytie sviatoi Varvary," 87.

19 N. Petrov and I. Shliapkin wrote about the manuscript with the description of miracles resulting from St. Barbara's relics, rewritten by D. Tuptalo. But M. Fedotova claims that this manuscript is lost. See more in the paper by M. Fedotova mentioned above.

20 Derek Krueger, "Writing as Devotion: Hagiographical Composition and the Cult of the Saints in Theodoret of Cyrrhus and Cyril of Scythopolis," Church History 66.4 (1997): 707-19. 
Tuptalo's Chetii-Minei included all the stories on saints' lives written by Cyril, ${ }^{21}$ each of them with its own history of perception. For example, the best-known text in Rus about Sava the Sanctified (December 5) was known in two versions (as noted by Tuptalo himself): one written by Cyril and the other by Metaphrastes. Cyril's text was translated into Church Slavonic, became very popular beginning in the 12th century, and was then reproduced in many manuscripts. Respectively, Tuptalo's text was more influenced by Cyril's text. A quite extensive passage about the acquaintance of Cyril and Sava (written in the original as a first-person narrative) and about the beginning of their relationship of teacher and disciple is reduced to one sentence, but is still preserved. Tuptalo wrote the narrative in the third person and explained who Cyril was and how important it was that he was as a disciple, a monk and an author ("and there he had seen this small boy Cyril (who this Life had written), named him his disciple, prophesied about him, that he would be a monk in his monastery"). ${ }^{22}$ In the Life of Euthymios (January 11) Cyril is mentioned as an author at the end of the text in the reference to another more complete version of Euthymios' Life (in a margin we find notes on both of them: Cyril of Scythopolis and Metaphrastes). In the Life of Kyriakos (September 29) Cyril is not only mentioned as the previous author, but Dymytriy also updated a large part of Cyril's text with very interesting stories about the author's travels between Palestinian monasteries, meetings with Kyriakos, St. John the Hesychast, a narrative by John, a disciple of Kyriakos, and a story about Saint Maria of Egypt. Now and then Tuptalo reminds the reader that the narrator is Cyril, the narrator's "me" is always clarified. The Life of John the Hesychast (December 3 ) is also written, as Tuptalo claims, using texts from the two authors: Cyril of Scythopolis and Metaphrastes. Likewise, Dymytriy quotes Cyril's direct speech in which he relates his personal communication with St. John. This citation is quite extensive. After that D. Tuptalo continues to write about Cyril's experience in the third person.

It is interesting how Tuptalo deals with texts from previous authors, in Martyrdom of Tarachus, Probus and Andronicus (October 12). At the beginning of the narration he marks in a margin: "Scriveners and then Metaphrastes." This way Tuptalo consistently writes a story of suffering and the death and burial of martyr saints, pointing very comprehensively in a margin to the sources of information, noting time and circumstance: "To this moment it was written by the judicial scribes, they had been writing while the saints suffered torment." ${ }^{23}$ The next part of information was from the "three pious men, witnesses, their names were Makarius, Phelix and Veriy." The fact of knowing the names of these men is very exciting for Dymytriy (we know

21 Not all of them are noted as written by Cyril of Scytopolis. For example, the Life of Theodosius the Cenobiarch is marked as Metaphrastes' text. Eduard Schwartz, Kyrillos von Skytopolis. TU49/2 (Leipzig: J. C. Hinrichs Verlag, 1939). Hereinafter, for convenience, the citation is translated from the new edition in modern Ukrainian (Coherence with the first editions of 1689, 1695, 1700, 1705 years is confirmed). "Zhytie Savy Osviachenoho," ["The Life of St. Sava,"] in Zhytia Sviatykh by Dmytro Tuptalo, transl. V. Shevchuk and D. Syroid (Lviv: Svichado, 2007), 133. More about in: Dariya Syroyid, "Dymytriy Tuptalo i Petro Skarga kriz pryzmu Zhytia Sviatoho Savy," ["Dymytriy Tuptalo i Petro Skarga in the Light of The Life of Saint Sava,"] Ukrainske literaturoznavstvo 77 (2013): 307-14. 
nothing more about them, just the names). Memory not only of the saints but also of the people who retained this memory is very important for him.

In some cases Dymytiy Tuptalo did not interfere with the author's text at all. The Life of Mary of Egypt was not rewritten by Tuptalo. This is a text by Sophronios, patriach of Jerusalem, and this fact is indicated at the beginning of the text, under the title. The text has an interesting narrative situation, because Mary's entire story is known from the monk Zosyma. Sophronios as an author appears at the beginning and at the end of the text (frame-narration and inserted narrator) and Tuptalo consistently explains that these words belong to Sophronios. He does not change the words: "I shall in no way keep silent with regard to the holy tale which has reached me," ${ }^{24}$ but he adds "Sophronios talks." 25 Tuptalo acts similarly at the end of text when Sophronios notes that "I have put down in this written narrative what I had heard by word of mouth." 26

The Life of Saint Onuphrius, written by Paphnutius the Ascetic (June 12), and some other texts, for example about the martyr Vasilisk (May 23) also belong to this group of unchanged texts. In these texts we have not only popular saints, but also outstanding interesting stories about them, popular for many centuries. Further examples open for us one of the paradigms of Tuptalo's authorship: authorship as responsibility. Detailed remarks about the author, explanation of the author's "I" not just disclose the true author of the original text, but also represent the compiler as a mediator, a person who only presents the text and testifies to its authenticity.

A special group of texts (38 texts) originate from The Kyivan Cave Patericon and are dedicated to the monk saints of the Kyiv Cave Monastery. Archbishop Ihor Isichenko writes about them in his article "The Ascetic Tradition of the Kyiv-Pechersk Monastery in the Hagiographic Discourse of St. Dymytriy Tuptalo." ${ }^{27}$ All of them except three were preserved in the original form. Archbishop Ihor interprets this interesting fact as the special concept and discourse strategy by Saint Dymytriy and claims that these texts in their authentic form made an impact on the other texts in the collection. ${ }^{28}$ They also serve as an example of reusing material in the new genre, now called a "life." One should not forget about the changes of the concept of the genre, expansion of the boundaries of genre rules, and the creation of a new understanding of the genre and its possibilities during the baroque period.

One of the three texts that were changed is The Life of Saint Theodosius. Directly under the title Tuptalo indicates that the main author of this text is Reverend Nestor, and the source of it is

24 The English translation of this passage is from the book: Alice-Mary Talbot, ed., Holy Women of Byzantium: Ten Saint's Lives in English Translation (Washington: Dumbarton Oaks Research Library and Collection, 1996), 70 . dyskursi svt. Dymytria Tuptala," ["The Ascetic Tradition of the Kyivan-Pechersk Monastery in the Agiographic Discourse of St. Dmytro Tuptalo,"] in Dmytro Tuptalo u sviti ukrainskoho baroko, ed. Bohdana Krysa (Lviv: Artos — Apriori, 2007), 7-14.

28 Isichenko, "Asketychna tradytsiia," 9. 
The Kyivan Cave Patericon. He also mentions that he truncated Nestor's text. This reduction is authorial and shows that this text was also special for him. ${ }^{29}$

The attempt to trace Dymytriy's work back to medieval texts about the famous martyrs of faith Boris and Hlib was done by Nazar Fedorak. ${ }^{30}$ Tuptalo's story about the princes saints is additional proof of his responsible writing technique. All available information concerning the saints that were special to him is presented in his own expressions and is well composed and discreet.

In fact, this type of re-writing is demonstrated by the first text in Chetii-Minei - The Life of Symeon the Stylite. The list of references at the beginning is long and their traces in the text are significant. The text is brief and complete at the same time. The reader feels the presence of all the previous and the most recent authors. Dymytriy Tuptalo is not among them. He is next to the reader revealing and demonstrating sanctity in the history of its perception. Eventually, the favourite way of baroque authors to sign their works is to hide the name of the author in an acrostic, can serve as a metaphor of Tuptalo's latent presence as an author in the Lives of the Saints collection. Tuptalo did the same in his compendium.

\section{Bibliography}

"Apokryfy i lehendy z ukrainskykh rukopysiv." ["Apocrypha and Legends in Ukrainian Manuscripts."] In Apokryfy novozavitni, apokryfichni diiannia apostoliv, edited by Ivan Franko, 33-45. Lviv, 2006. Originally published in 1902.

Cicero, Quintus Tullius. "Handbook on Canvassing for the Consulship." In Rome: Late Republic and Principate, edited by Walter Emil Kaegi Jr. and Peter White. Vol. 2 of University of Chicago Readings in Western Civilization, edited by John Boyer and Julius Kirshner, 33-46. Chicago: University of Chicago Press, 1986. Originally published in Evelyn S. Shuckburgh, trans., The Letters of Cicero, vol. 1 (London: George Bell \& Sons, 1908).

Bilous, Petro. "Pytannia psykholohii tvorchosty v 'Diariushi' Dmytra Tuptala." ["The Problem of the Psychology of Art in Dmytro Tuptalo's Diary."] In Dmytro Tuptalo u sviti ukrainskoho baroko, edited by Bohdana Krysa, 64-71. Lviv: Artos - Apriori, 2007.

Ceccherelli, Andrea. "Od Suriusa do Skargi / Studium porównawcze o ‘Żywotach świętych.” In Nauka o literaturze polskej za granica, pod redakcją naukową Aliny Nowickiej-Jeżowej, tom VIII). Translated by Monika Niewójt. Warszawa: Świat Literacki, 2003.

Derzhavin, A. "Chetii-Minei sviatitelia Dimitria, mitropolita Rostovskogo, kak tserkovnoistoricheskii i literaturnyi pamiatnik." ["The Chetii-Minei of Dmytro, Metropolitan

29 For a short analysis of 'Theodosius Life' in Tuptalo's compendium see: Dariya Syroyid, “Zhanr zhytia v ‘Chetiakh-Mineiakh' svt. Dymytria (Tuptala),” [“The Genre of 'Life' in Dmytro Tuptalo's The Chetii-

Minei,"] in Dmytro Tuptalo u sviti ukrainskoho baroko, ed. Bohdana Krysa (Lviv: Artos - Apriori, 2007), 42-49.

30 Nazar Fedorak, "Boryso-Hlibskyi siuzhet u 'Zhytiiakh Sviatykh' Dmytra Tuptala," ["The Story of the Saints Borys and Hlib in Dmytro Tuptalo's Lives of the Saints,"] in Dmytro Tuptalo u sviti ukrainskoho baroko, ed. Bohdana Krysa (Lviv: Artos - Apriori, 2007), 50-63. 
of Rostov, as Clerical, Historical, and the Literary Evidence."] Bogoslovkie trudy 15 (1976): $61-145$.

Høgel, Christian. Symeon Metaphrastes: Rewriting and Canonization. Copenhagen: Museum Tusculanum Press, 2002.

Fedorak, Nazar. "Boryso-Hlibskyi siuzhet u 'Zhytiiakh Sviatykh' Dmytra Tuptala." ["The Story of the Saints Borys and Hlib in Dmytro Tuptalo's Lives of the Saints."] In Dmytro Tuptalo u sviti ukrainskoho baroko, edited by Bohdana Krysa, 50-63. Lviv: Artos - Apriori, 2007.

Fedotova, Marina. "Zhytie sviatoi Varvary v Drevnei Rusi." ["The Life of St. Barbara in Kyivan Rus."] In TODRL, vol. 53, 76-89. Saint Petersburg, 2003.

Isichenko, Ihor, Arch. "Asketychna tradytsiia Kyievo-Pecherskoho monastyria v ahiohrafichnomu dyskursi svt. Dymytria Tuptala." "The Ascetic Tradition of the Kyivan-Pechersk Monastery in the Agiographic Discourse of St. Dmytro Tuptalo."] In Dmytro Tuptalo u sviti ukrainskoho baroko, edited by Bohdana Krysa, 7-14. Lviv: Artos - Apriori, 2007.

Johnson, Scott Fitzgerald. The Life and Miracles of Thekla: A Literary Study. Cambridge, MA and London: Harvard University Press Center for Hellenic Studies, 2006.

Krueger, Derek. "Writing as Devotion: Hagiographical Composition and the Cult of the Saints in Theodoret of Cyrrhus and Cyril of Scythopolis." Church History 66.4 (1997): 707-19.

Krueger, Derek. Writing and Holiness. The Practice of Authorship in the Early Christian East. Philadelphia: University of Pennsylvania Press, 2004.

Pachovskyi, Teoktyst. “Knyha Zhytii sviatykh' Dmytra Tuptalenka-Rostovskoho." [“Dmytro Tuptalenko-Rostovskyi's Lives of the Saints."] In Dmytro Tuptalo u sviti ukrainskoho baroko, edited by Bohdana Krysa, 221-26. Lviv: Artos - Apriori, 2007.

Rapp, Claudia. "Byzantine Hagiographers as Antiqurians, 7th to 1oth Century." In Bosphorus, edited by C. Rapp, S. Efthymiadis, D. Tsougarakis, 31-44. Amsterdam, 1995.

Schwartz, Eduard. Kyrillos von Skytopolis. TU49/2. Leipzig: J. C. Hinrichs Verlag, 1939.

Syroyid, Dariya. "Dymytriy Tuptalo i Petro Skarga kriz pryzmu Zhytia Sviatoho Savy." ["Dymytriy Tuptalo i Petro Skarga in the Light of The Life of Saint Sava."] Ukrainske literaturoznavstvo 77 (2013): 307-14.

Syroyid, Dariya. "Zhanr zhytia v 'Chetiakh-Mineiakh' svt. Dymytria (Tuptala)." ["The Genre of 'Life' in Dmytro Tuptalo's The Chetii-Minei."] In Dmytro Tuptalo u sviti ukrainskoho baroko, edited by Bohdana Krysa, 42-49. Lviv: Artos - Apriori, 2007.

Talbot, Alice-Mary, ed. Holy Women of Byzantium: Ten Saint's Lives in English Translation. Washington: Dumbarton Oaks Research Library and Collection, 1996.

Tuptalo, Dymytriy. "Diariush." ["Diary."] In Pamiatna knyha Dmytra Tuptala, edited by Valentyna Sobol, 36-37. Warsaw: Uniw. Warszawski, 2004.

Tuptalo, Dymytriy. Knyha Zhytii Sviatykh [Lives of the Saints]. 4 volumes. Kyiv, 1689, 1695, 1700, 1705 .

Tuptalo, Dmytro. Zhytia Sviatykh [Lives of the Saints]. Translated in Modern Ukrainian by Valeriy Shevchuk and Dariya Syroyid. 12 volumes. Lviv: Svichado, 2005-2014. 
Dariya Syroyid, $\mathrm{PhD}$ in Philology, is a lecturer at Ukrainian Catholic University. Her research interests cover a wide range of themes in medieval and early modern literature, especially hagiography (original works, works by the Monk Nestor (Nestor the Chronicler), and works translated from Greek into Church Slavonic). Currently, she is particularly interested in hagiographical metaphraseis (re-writing). Dr. Syroyid has translated a part of Kyrylo Tranquilion Stavrovetskyi's Didactic Gospel (Lviv, 2014) and 10 (of 12) volumes Dymytriy Tuptalo's Lives of the Saints (Lviv, 2007-2015) into modern Ukrainian. 